\title{
ИНТЕНСИФИКАЦИЯ ХЛЕБОПЕКАРНЫХ ДРОЖЖЕЙ С ПОМОЩЬЮ ВОДОРАСТВОРИМОГО ФУЛЛЕРЕНА
}

\author{
A.I. Mashanov, G.N. Churilov, N.N. Tipsina, \\ N.G. Vnukova, N.V. Prisukhina, A.A. Mashanov

\section{THE INTENSIFICATION OF BAKING YEAST WITH WATER-SOLUBLE FULLERENE}

\begin{abstract}
Машанов Александр Иннокентьевич - д-р техн. наук, проф. кафр. технологии консервирования и пищевой биотехнологии Красноярского государственного аграрного университета, г. Красноярск. E-mail: fppp@kgau.ru

Чурилов Григорий Николаевич - д-р техн. наук, проф., зав. лаб. аналитических методов исследования вещества Института физики им. Л.В. Киренского СО РАН, г. Красноярск.

E-mail: churilov@iph.krasn.ru

типсина Нэлля Николаевна - д-р техн. наук, проф. каф. технологий хлебопекарного, кондитерского и макаронного производств Красноярского государственного аграрного университета, г. Красноярск.

E-mail: txkimp@mail.ru
\end{abstract}

Внукова Наталья Григорьевна - канд. техн. наук, науч. сотр. лаб. аналитических методов исследования вещества Института ффизики им. Л.В. Киренского СО РАН, г. Красноярск.

E-mail: churilov@iph.krasn.ru

Присухина Наталья Викторовна - канд. техн. наук, доц. каф. технологий хлебопекарного, кондитерского и макаронного производств Красноярского государственного аграрного университета, г. Красноярск.

E-mail: nat3701@mail.ru

Машанов Александр Александрович - канд. мед. наук, доц. каф. современных образовательных технологий Института педагогики, психологии и социологии Сибирского федерального университета, г. Красноярск. E-mail: nat3701@mail.ru

В работе изучалась возможность использования водорастворимого фуллерена в производстве хлеба. Фуллерены - это аллотропнная модификация углерода. Они биологически активны и используется в медицине, в качестве антиоксидантов, радиопротекторов, противогрибковых и других агентов. Поэтому возник интерес по изучению влияния водорас-
Mashanov Alexander Innokentyevich - Dr. Techn. Sci., Prof., Chair of Technology of Canning and Food Biotechnology, Krasnoyarsk State Agrarian University, Krasnoyarsk.

E-mail: fppp@kgau.ru

Churilov Grigory Nikolayevich - Dr. Techn. Sci., Prof., Head, Lab. of Analytical Methods of Substance Research, L.V. Kirensky Institute of Physics SB RAS, Krasnoyarsk.

E-mail: churilov@iph.krasn.ru

Tipsina Nellya Nikolayevna - Dr. Techn. Sci., Prof., Chair of Technology of Baking, Confectionery and Macaroni Productions, Krasnoyarsk State Agrarian University, Krasnoyarsk.

E-mail: txkimp@mail.ru

Vnukova Natalya Grigoryevna - Cand. Techn. Sci., Staff Scientist, Lab. of Analytical Methods of Substance Research, L.V. Kirensky Institute of Physics SB RA S, Krasnoyarsk.

E-mail: churilov@iph.krasn.ru

Prisukhina Natalya Victorovna - Cand. Techn. Sci., Assoc. Prof., Chair of Technologies of Baking, Confectionery and Macaroni Productions, Krasnoyarsk State Agrarian University, Krasnoyarsk.

E-mail: nat3701@mail.ru

Mashanov Alexander Alexandrovich - Cand. Med. Sci., Assoc. Prof., Chair of Modern Educational Technologies, Institute of Pedagogics, Psychology and Sociology, Siberian Federal University, Krasnoyarsk.

E-mail: nat3701@mail.ru

творимого ффуллерена на хлебопекарные дрожжи и процесс брожения при производстве хлеба. Основными факторами, влияющими на технологический процесс и качество готовых хлебобулочных изделий, является биологическая активность дрожжей и молочнокислых бактерий. В работе в качестве контрольного образиа выбрана рецептура хлеба пшеничного 
из муки высшего сорта. Фуллерен растворялся в воде и вносился в виде водного раствора при замесе теста. Замес проводили вручную на дрожжах фрирмы Angel, способ приготовления хлеба выбран ускоренный. Перед замесом теста проводили активацию дрожжей в воде (контроль) и в растворах фулеррена $(1 ; 1,5 ; 2$; 3; 4 и 4,5 \%) с добавлением 10 \% муки от ее количества, идущего на замес. Активацию проводили в течение 20 и 60 минут и наблюдали за образованием «пенной шапочки». $B$ результате в образцах с добавлением водорастворимого фруллерена с увеличением количества добавки наблюдалось увеличение объема «nенной шапочки», что говорит об активизации деятельности дрожжей и ускорении процесса брожения. Готовые образцы изделий исследовали по основным показателям качества. Результаты показали, что с добавлением водорастворимого фуллерена изменялась окраска изделий, незначительно увеличивалась кислотность при прочих равных условиях, что тоже говорит о более быстром кислотонакоплении, что влияет на процесс созревания теста и продолжительность брожения. Пористость готового хлеба также увеличивалась с увеличением дозировки фруллерена. В результате проведенных исследований по влиянию водорастворимого фуллерена на хлебопекарные свойства дрожжей установлено его положительное влияние на процесс брожения и качество хлеба.

Ключевые слова: фуллерен, хлеб, брожение, технология, показатели качества.

The possibility of using water-soluble fullerene in bread production was studied in the research. Fullerenes are allotropic carbon modification. They have biological activity and used for medical purposes as antioxidants, radioprotectors, antifungal and other agents. In this regard there was interest in studying the influence of water-soluble fullerene on baking yeast and fermentation process in bread production. One of the main factors affecting technological process and the quality of bakery products is biological activity of the yeast and lactic acid bacteria. In the study the control sample was selected for the recipe of wheat bread from premium flour. Fullerene was dissolved in water and introduced as an aqueous solution when kneading the dough. Kneading was carried out manually on the yeast of the firm 'Angel'; accelerated method of preparing bread was selected. Before kneading the batch yeast activation was performed in water (control) and in fullerene solutions (1, 1.5, 2, 3, 4 and $4.5 \%)$ with the addition of $10 \%$ flour from the amount of flour which was to be used in the batch. The activation was performed for 20 and 60 minutes and the formation of a "foam cap" was observed. As a result, the samples with the addition of water-soluble fullerenes with increasing amount of additives, had an increase in the amount of "foam hats", testifying about the revitalization of the yeast and accelerate fermentation. Finished product samples were examined by the main quality indicators. The results showed that after the addition of water-soluble fullerene the color of the products changed, the acidity slightly increased, other things being equal, which also indicated a faster acid accumulation, affecting the maturation process of the dough and the duration of fermentation. The porosity of finished bread also increased with growing of the dosage of fullerene. As a result of conducted research on the influence of water-soluble fullerene on baking properties of yeast a positive effect on the fermentation process and the quality of bread was established.

Keywords: fullerene, bread, fermentation, technology, quality indicators.

Введение. Одна из самых актуальных задач современной науки - это поиск соединений, которые способны отодвинуть старость и продлить жизнь. Известие о том, что французским ученым удалось добиться увеличения продолжительности жизни животных, участвовавших в эксперименте при применении фуллеренов (наночастиц углеродной природы), почти вдвое заставило ученых-исследователей задуматься над молекулярными механизмами подобного эфффекта.

Фуллерены - это довольно необычный класс молекул, представляющих собой одну из форм аллотропных модификаций углерода. К аллотропным формам углерода также относятся всем известные алмаз и графит. Всем известные алмаз и графит - тоже не что иное, как аллотропные формы углерода, однако структура атомов углерода алмаза представлена в виде тетраэдра, графит образован в виде шестиугольников из плоских слоев, а фуллерены - это шарообразные молекулы с замкнутой поверхностью. Самый простой из фуллеренов содержит 60 атомов углерода и напоминает по своей структуре футбольный мяч: его поверхность образована чередующимися пяти- и шести- 
угольниками, причем размер этого «мяча» составляет всего 1 нм (нанометр).

Водорастворимые фуллерены обладают широким спектром биологической активности, используются при создании медицинских и фармакологических препаратов: радиопротекторов, антиоксидантов, противогрибковых, противовирусных и бактериальных агентов [1-4].

В связи с этим изучение влияния водорастворимого фуллерена на микроорганизмы, В частности на хлебопекарные дрожжи и молочнокислые бактерии, представляет огромный интерес.

Дрожжи используются повсюду в мире для приготовления хлеба. Ценность дрожжей состоит в их способности с высокой эфффективностью превращать высокие концентрации сахаров в спирт, углекислый газ и образовывать дрожжевую биомассу, богатую белками, витаминами.

В технологическом процессе приготовления хлеба главную роль играют дрожжи и молочнокислые бактерии. В результате жизнедеятельности дрожжей из сахаров образуется углекислый газ, разрыхляющий тесто, и небольшое количество спирта. Молочнокислые бактерии, образуя молочную кислоту и некоторые органические кислоты, повышают кислотность теста, создавая хорошие условия для развития дрожжей.

Технологический процесс производства хлеба состоит из следующих операций: подготовка сырья, замес, брожение, разделка, расстойка теста, выпечка.

В производстве хлеба главными разрыхлителями теста являются хлебопекарные дрожжи, вносимые в определенном количестве при замесе теста.

Основным фактором, влияющим на технологический процесс и качество хлебобулочных изделий, является биологическая активность дрожжей, молочнокислых бактерий.

С целью активации жизнедеятельности дрожжей и молочнокислых бактерий готовятся различные питательные среды - закваски. Для активации дрожжей используются электрохимические обработки [4]. Это способствует сокращению сроков приготовления теста, снижает затраты сухих веществ на брожение и увеличивает выход готовой продукции на 12-15 процентов [5].

Актуальной задачей, стоящей перед хлебопекарной промышленностью, является ускоре- ние технологического процесса и повышение качества готовой продукции.

Цель исследования. Изучить влияние водорастворимого фруллерена на бродильную активность хлебопекарных дрожжей и качество хлеба.

Задачи исследования: изучить влияние водорастворимого фуллерена на биологическую активность хлебопекарных дрожжей; определить влияние водорастворимого фуллерена на показатели качества хлеба.

Материалы и методы исследования. Органолептические показатели определяли после остывания хлебобулочных изделий по ГОСТ 5667-65, кислотность по ГОСТ 5670-96, пористость по ГОСТ 5669-96, влажность по ГОСТ 21094-75, удельный объем хлеба (метод, характеризующий пористость хлебобулочных изделий, его внешний вид), жизнеспособность дрожжей оценивали методом витального окрашивания [5].

В качестве исходного материала был взят хлеб из муки пшеничной высшего сорта (табл. 1). Опыты с водорастворимым фуллереном проводились в 2 этапа. Исследования в первом этапе показали хорошие результаты, поэтому был проведен второй этап с уменьшением количества водорастворимого фуллерена.

$$
\text { 1-ŭ эman }
$$

1. Вариант опыта 1 - контрольный образец без фуллерена.

2. Вариант опыта 2 - с внесением 1,5\% фуллерена.

3. Вариант опыта 3 - с внесением 3 \% фуллерена.

4. Вариант опыта 4 - с внесением 4,5\% фуллерена.

$$
\text { 2-ŭ эman }
$$

1. Вариант опыта 1 - контрольный образец без фуллерена.

2. Вариант опыта 5 - с внесением $1 \%$ фуллерена.

3. Вариант опыта 6 - с внесением $2 \%$ фулллерена.

4. Вариант опыта 7 - с внесением $4 \%$ фуллерена.

Фуллерен растворялся в воде и вносился в виде раствора при замесе теста. Замес проводился вручную. В качестве дрожжевой культуры использовались прессованные дрожжи марки «Angel» (Китай). В таблице 1 представлена рецептура хлеба. 
Рецептура хлеба белого пшеничного в/с [6]

\begin{tabular}{|l|c|}
\hline \multicolumn{1}{|c|}{ Сырье } & Количество сырья, г \\
\hline Мука в/с & 100 \\
\hline Дрожжи прессованные & 2,5 \\
\hline Соль & 1,5 \\
\hline
\end{tabular}

Хлеб готовили ускоренным способом на прессованных дрожжах. Тесто замешивали сразу из всего сырья, идущего по рецептуре, в один прием.

Перед замесом теста была проведена активация дрожжей. С этой целью рассчитанное по рецептуре количество дрожжей растворялось в теплой воде $\left(30{ }^{\circ} \mathrm{C}\right)$. Предварительно в этой воде растворялся фуллерен в зависимости от варианта опыта. Затем сюда добавляли муку в количестве $10 \%$ от общей массы, идущей на замес. Полученная смесь выдерживалась при комнатной температуре в течение 20 минут. После активации дрожжей в суспензию вносилось оставшееся сырье согласно рецептуре и проводился замес теста до однородной структуры в первом варианте. Во втором варианте замешивали опару и выдерживали ее в течение 60 минут, далее проводили замес теста.

Полученное таким образом тесто ставилось в расстоечный шкаф и выдерживалось при температуре $35^{\circ} \mathrm{C}$ в течение 150 минут [2].

В процессе брожения теста проводили 2 обминки через каждые 60 минут. Обминка представляет собой повторный промес в течение 1,5-2 мин для равномерного распределения

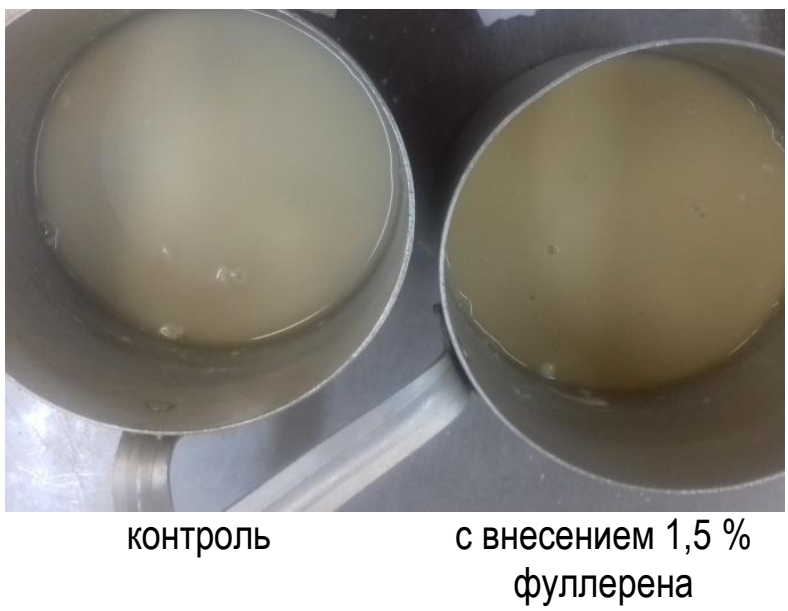

пузырьков воздуха и выход в окружающую среду углекислого газа из теста, при этом улучшается качество теста, мякиш готового хлеба приобретает равномерную мелкую пористость.

После процесса брожения тесто делилось на куски массой по 200 г, и им придавалась форма. Готовые тестовые заготовки помещались в малые формы. Заготовки теста снова помещались в расстоечный шкаф для окончательной расстойки с температурой $35{ }^{\circ} \mathrm{C}$. Окончание расстойки определяли по внешнему виду.

Выпекали хлеб в печи при температуре $220^{\circ} \mathrm{C}$ в течение 22-25 минут. Качество хлеба оценивали по следующим показателям: запах, внешний вид, пористость. По физико-химическим показателям: удельный объем $\left(\mathrm{cm}^{3}\right)$ и кислотность (град).

Результаты исследования и их обсуждение. Результаты исследования показали, что внесение водорастворимого фуллерена для активации дрожжей во всех концентрациях сравнительно выше, чем в контроле. В образцах с фуллереном образовалась более объемная «пенная шапочка» из дрожжей (рис. 1-5). Процесс активации начался быстрее, чем в контроле.

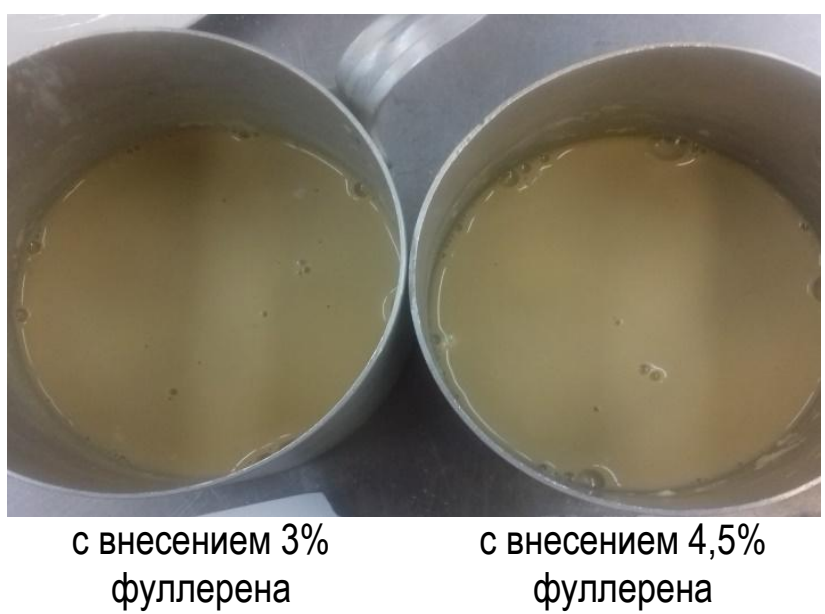

Рис. 1. Внешний вид раствора дрожжей в различных образцах 


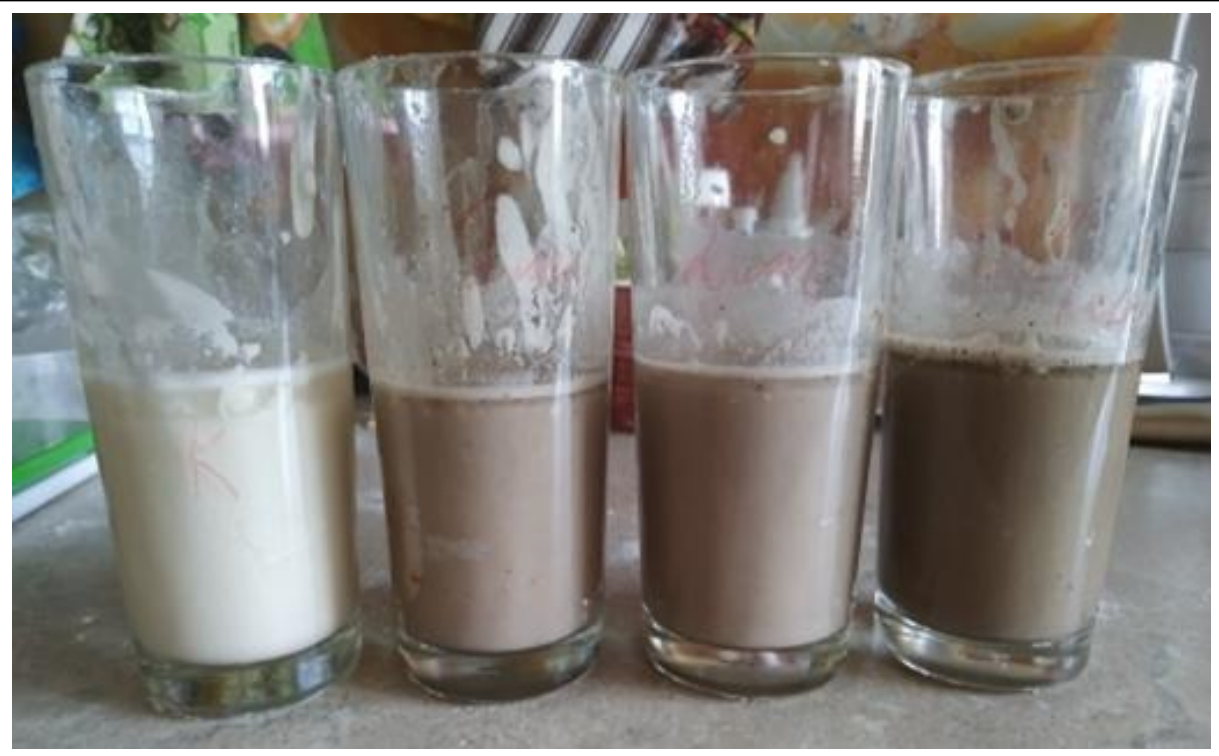

Puс. 2. Внешний вид и высота «пенной шапочки» сразу после замеса опары

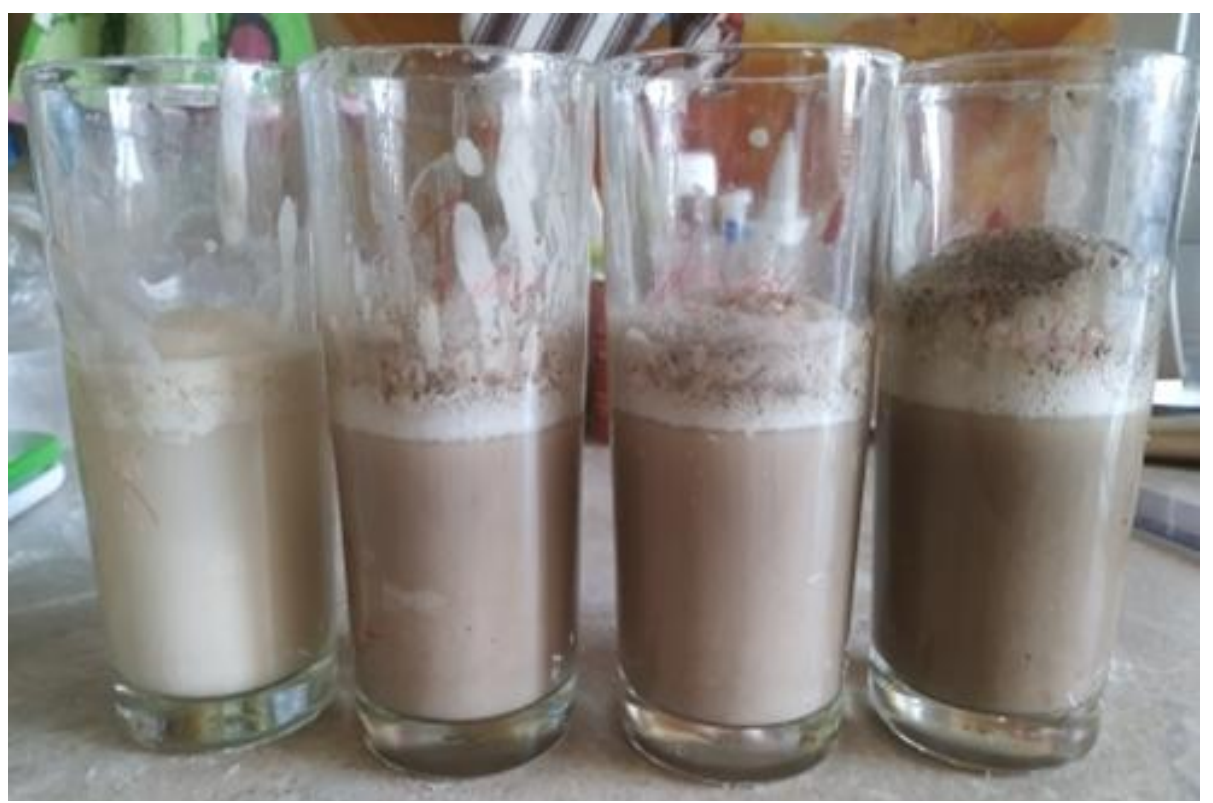

Pис. 3. Внешний вид и высота «пенной шапочки» через 20 мин брожения опары

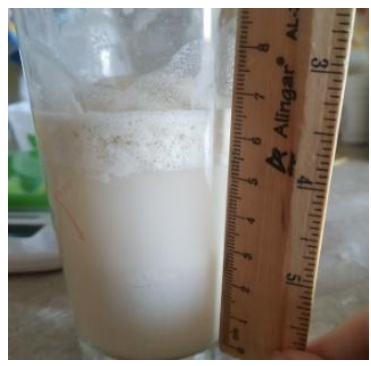

7 см - контроль

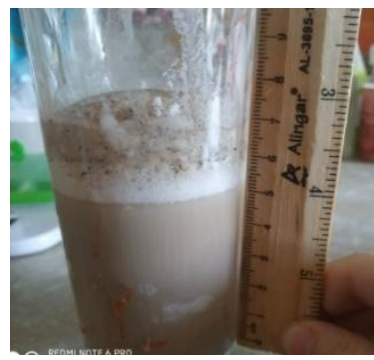

7,5 см - с внесением $1 \%$ фуллерена

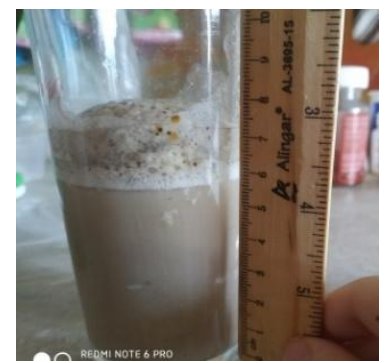

7,8 см - с внесением $2 \%$ фуллерена

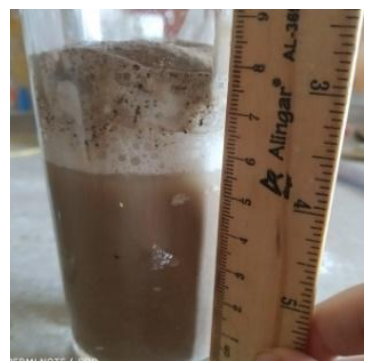

$8,5 \mathrm{~cm}-$ с внесением $4 \%$ фуллерена

Puc. 4. Высота «пенной шапочки» после 60 минут брожения опары, см 


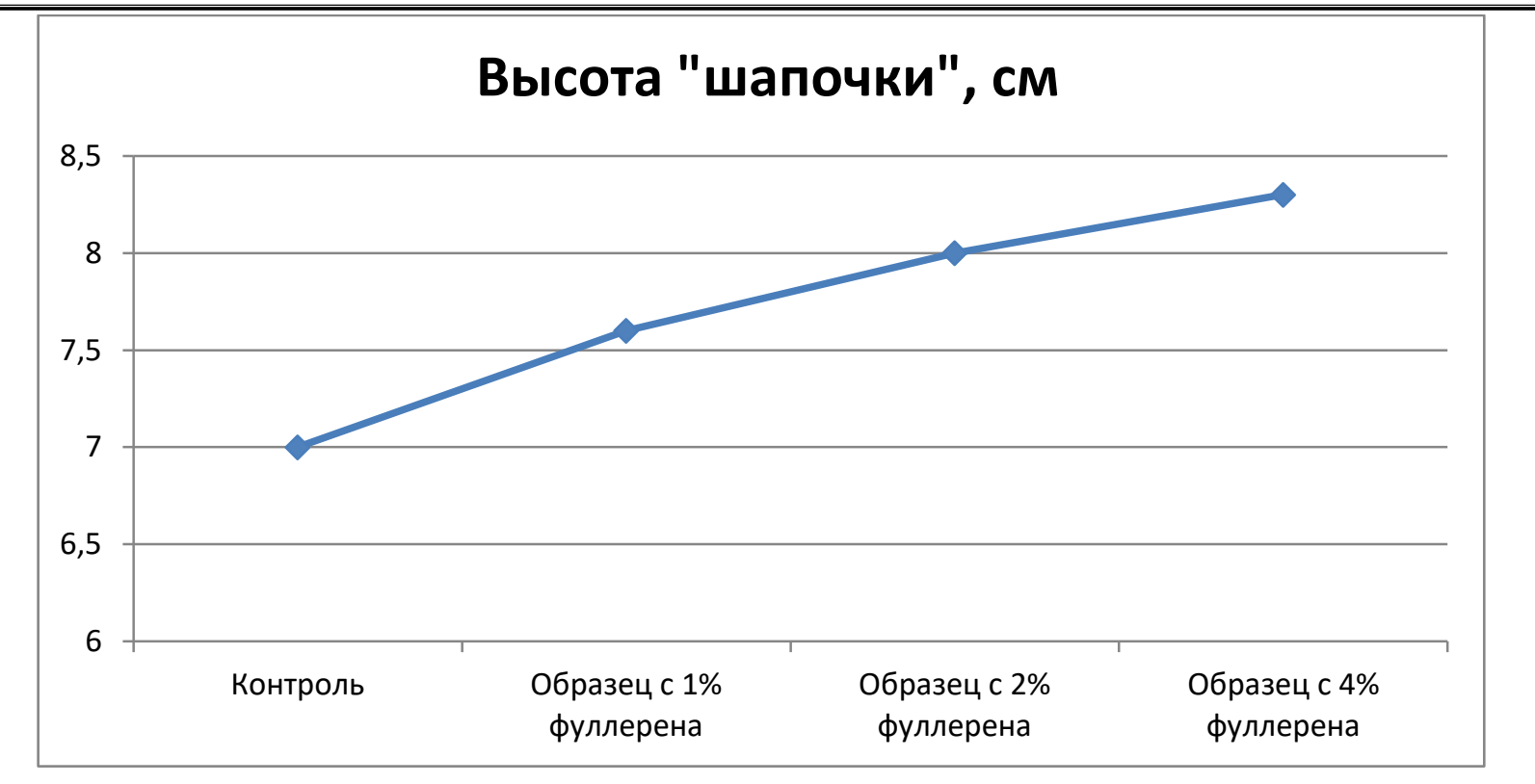

Puc. 5. Высота «пенной шапочки»

Результаты исследования по выпечке хлеба показали следующее: тестовые заготовки и готовые изделия с увеличением количества фуллерена в образцах по своей высоте становились выше, чем в контрольном образце (рис. 69). Внешний вид хлеба с водорастворимым фуллереном отличался от контрольного образца: с увеличением количества добавки цвет готового изделия становился более темным. По своему запаху и вкусу хлеб с фуллереном не отличался от контрольного образца.

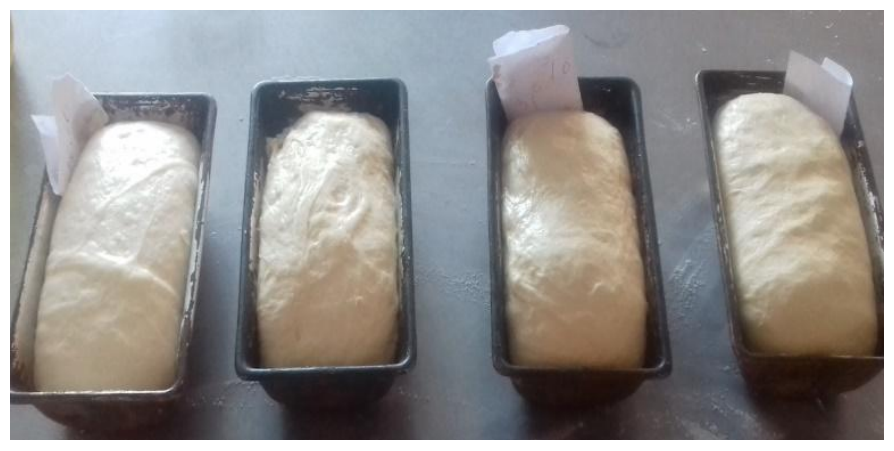

Рис. 6. Внешний вид тестовых заготовок после расстойки (варианты 1, 2, 3, 4)

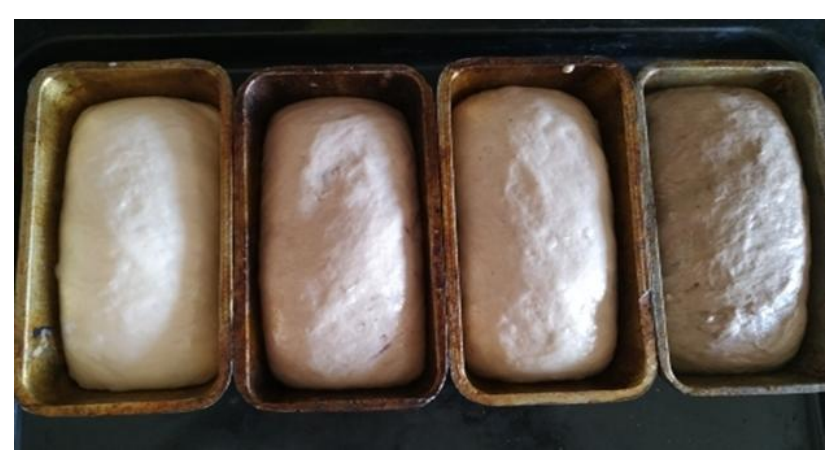

Pис. 7. Внешний вид тестовых заготовок после расстойки (варианты 1, 5, 6, 7) 


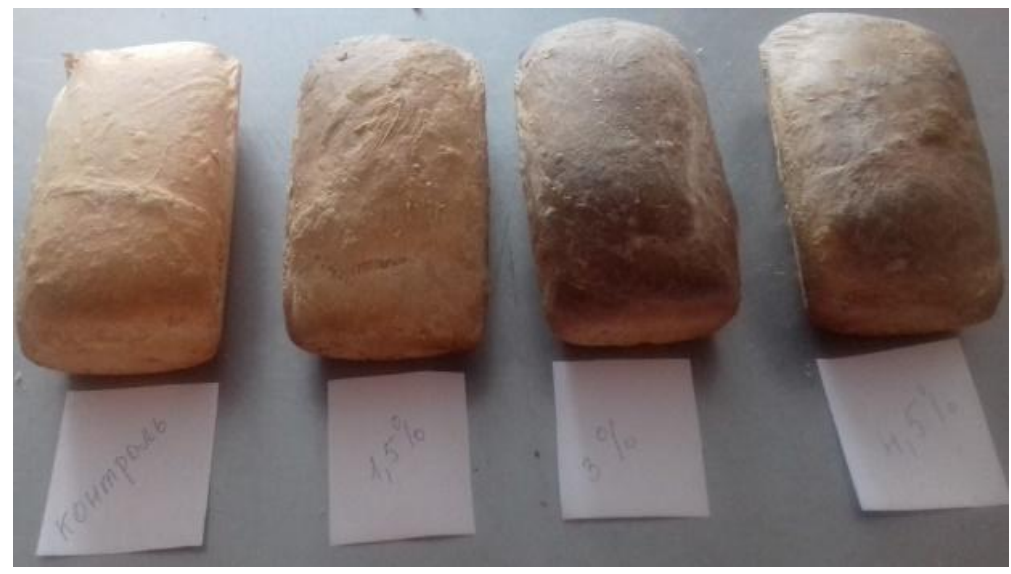

Pис. 8. Внешний вид готового хлеба (варианты 1, 2, 3, 4)

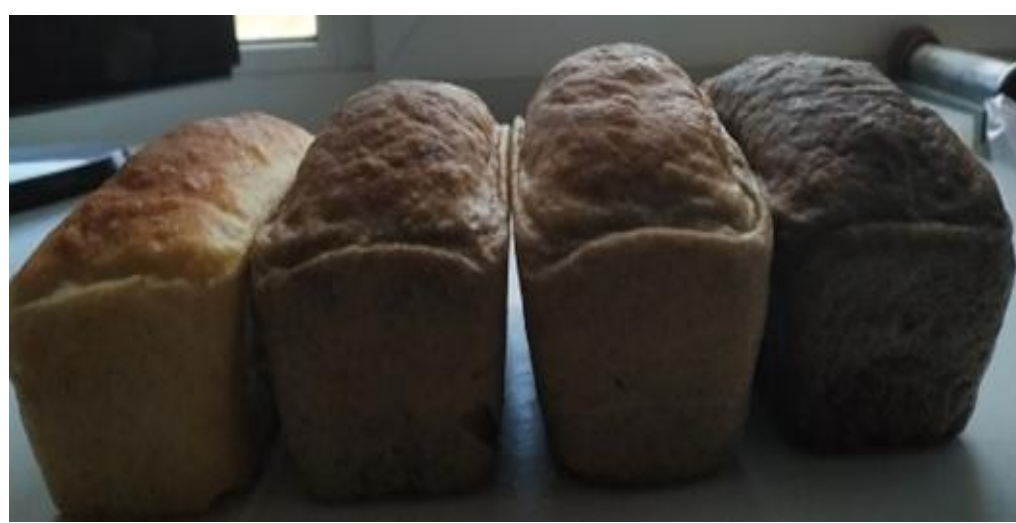

Pис. 9. Внешний вид готового хлеба (варианты 1, 5, 6, 7)

Результаты исследования фризико- увеличением дозировки становился выше, чем в химических показателей хлеба с водораствори- контроле. В образце с внесением 4,5 \% водомым фуллереном следующие: кислотность хле- растворимого фуллерена относительно конба с фуллереном увеличивалась незначительно трольного образца удельный объем увеличилс увеличением количества добавки и составля- ся, но снизился относительно варианта с дола от 2,6 до $3,3^{\circ} \mathrm{C}$, что соответствует требова- бавлением 3 \%. В таблице 2 приведены физикониям ГОСТ 31805-2018, кроме варианта № 4, химические показатели качества хлеба конгде показатель кислотности превышает допус- трольного образца и образцов 2-го, 3-го и 4-го тимое значение 3, что не соответствует требованиям. Удельный объем пшеничного хлеба с добавлением водорастворимого фуллерена с вариантов.

Результаты опытов по вариантам 5, 6, 7 представлены в таблице 3.

Таблица 2

\section{Физико-химические показатели качества хлеба}

\begin{tabular}{|l|c|c|c|c|}
\hline \multicolumn{1}{|c|}{ Показатель } & Вариант № 1 & Вариант № 2 & Вариант № 3 & Вариант № 4 \\
\hline Удельный объем, см ${ }^{3} / г$ & 0,49 & 2,58 & 0,69 & 0,69 \\
\hline Кислотность, град & 2,6 & 2,6 & 2,8 & 3,3 \\
\hline Пористость, \% & 78,2 & 79,8 & 78,3 & 77,8 \\
\hline Влажность, \% & 40 & 40 & 40 & 40,3 \\
\hline
\end{tabular}


Показатели качества хлеба

Таблица 3

\begin{tabular}{|c|c|c|c|c|}
\hline Показатель & Вариант № 1 & Вариант № 5 & Вариант № 6 & Вариант № 7 \\
\hline Окраска корки & Светло-желтая & $\begin{array}{l}\text { Светло- } \\
\text { коричневая }\end{array}$ & Коричневая & $\begin{array}{c}\text { Темно- } \\
\text { коричневая }\end{array}$ \\
\hline Поверхность & \multicolumn{4}{|c|}{ Без крупных трещин и подрывов } \\
\hline Форма & Правильная & Правильная & Правильная & Правильная \\
\hline Цвет мякиша & Белый & Светло-серый & Серый & Темно-серый \\
\hline Состояние мякиша & \multicolumn{4}{|c|}{ Эластичный, пропеченный, после нажатия восстанавливает свою фрорму } \\
\hline Состояние пористости & $\begin{array}{c}\text { Мелкая, } \\
\text { равномерная }\end{array}$ & \multicolumn{2}{|c|}{ Мелкая, равномерная } & $\begin{array}{l}\text { Мелкая, равно- } \\
\text { мерная }\end{array}$ \\
\hline Запах & \multicolumn{4}{|c|}{ Свойственный хлебу } \\
\hline Вкус & \multicolumn{4}{|c|}{ Свойственный хлебу } \\
\hline Масса хлеба, г & 153 & 153,4 & 153,5 & 157,6 \\
\hline Влажность, \% & 40 & 40 & 40 & 40,2 \\
\hline Удельный объем, см³ /г & 0,49 & 0,62 & 0,64 & 0,622 \\
\hline Кислотность, град & 2,6 & 2,8 & 2,8 & 3,2 \\
\hline Пористость, \% & 78,2 & 79,1 & 80,2 & 78,04 \\
\hline
\end{tabular}

Исследования показали, что у варианта № 6 наблюдались наилучшие показатели качества. При дальнейшем увеличении количества добавки хлеб приобретал очень темную окраску, а кислотность превышала значения требований ГОСТ 31805-2018. Вкус и запах не изменились. Увеличился выход готового изделия.

Заключение. В результате проведенных исследований по влиянию водорастворимого фуллерена на хлебопекарные свойства дрожжей установлено положительное влияние на процесс брожения хлебопекарного теста.

Кислотонакопление в тесте ускоряется от 3,0 град в контроле до 3,7 град в образцах свыше $4 \%$ фуллерена, сокращается технологическое время «подъема опары» на 25-30 мин.

Хлеб, приготовленный с добавлением водорастворимого фуллерена, обладает хорошими показателями качества. Наилучшими показателями обладает образец с дозировкой 3 \%. Хлеб имеет привлекательный вид, обладает хорошей пористостью (80\%), все показатели качества соответствуют требованиям ГОСТа.

Исследования по влиянию водорастворимого фуллерена на хлебопекарные дрожжи необходимо продолжить и расширить по снижению количества биологически активной добавки, а также по оценке возможности использования его в технологических процессах, связанных с использованием различных видов микрооргаНИзМОВ.

\section{Литература}

1. Baati T., Bourasset F., Gharb N., [et al] (2012). The prolongation of the lifespan of rats by repeated oral administration of 60 fullerence. Biomaterials 33, 4936-4946.

2. Manibusan M.K., Odin M., Eastmond D.A. (2007). Postulated carbon tetrachloride mode of action: a review. J. Environ. Sci. Health C Environ. Carcinog. Ecotoxical. Rev. 25, 185209.

3. Яйкова О.А., Томилин Ф.Н., Дубинина И.А. [и др.]. Свойства водорастворимых оксиполигидрокси фуллеренов в реакции автоокисления адреналина // Журнал Сибирского федерального университета. Серия. Химия. - 2015. - Т. 8. - № 4. - С. 533-540.

4. Nadezhda S. Kudryaasheva, Ekaterina S. Kovel, Anna S. Sachkova, Anna A. Vorobeva, Viktoriya G. Isakova and Grigoriy N. Churilov Bioluminescent Enzymatic Assay as a Tool for Studying Antioxidant Activity and Toxicity of Bioactive Compounds // Photochemistry and Photobiology. - 2017. - T. 93. - № 2. S. 536-540.

5. Корячкина С.Я., Березина Н.А., Хмелева E.B. Методы исследования качества хлебобулочных изделий: учеб.-метод. пособие для вузов. - Орел: ОрелГТУ, 2010. - 166 с. 
6. Ершов П.С. Сборник рецептур на хлеб и хлебобулочные изделия. - СПб.: Гидрометеоиздат, 1998. - 191 с.

\section{Literatura}

1. Baati T., Bourasset F., Gharb N., [et al] (2012). The prolongation of the lifespan of rats by repeated oral administration of 60 fullerence. Biomaterials 33, 4936-4946.

2. Manibusan M.K., Odin M., Eastmond D.A. (2007). Postulated carbon tetrachloride mode of action: a review. J. Environ. Sci. Health C Environ. Carcinog. Ecotoxical. Rev. 25, 185-209.

3. Yajkova O.A., Tomilin F.N., Dubinina I.A. [ldr.]. Svojstva vodorastvorimyh oksipoligidroksi fullerenov $v$ reakcii avtookisleniya adrenalina // Zhurnal Sibirskogo federal'nogo universiteta. Seriya. Himiya. - 2015. - T. 8. № 4. - S. 533-540.

4. Nadezhda S. Kudryaasheva, Ekaterina S. Kovel, Anna S. Sachkova, Anna A. Vorobeva, Viktoriya G. Isakova and Grigoriy N. Churilov Bioluminescent Enzymatic Assay as a Tool for Studying Antioxidant Activity and Toxicity of Bioactive Compounds // Photochemistry and Photobiology. - 2017. - T. 93. - № 2. S. 536-540.

5. Koryachkina S.Ya., Berezina N.A., Hmeleva E.V. Metody issledovaniya kachestva hlebobulochnyh izdelij: ucheb.-metod. posobie dlya vuzov. - Orel: OrelGTU, 2010 - $166 \mathrm{~s}$.

6. Ershov P.S. Sbornik receptur na hleb i hlebobulochnye izdeliya. - SPb.: Gidrometeoizdat, 1998. - 191 s. 